\title{
454 Sequencing
}

National Cancer Institute

\section{Source}

National Cancer Institute. 454 Sequencing. NCI Thesaurus. Code C146809.

A proprietary next-generation DNA sequencing system from 454 Life Sciences that used

large-scale parallel pyrosequencing. The system relied on fixing nebulized and adapterligated DNA fragments to small DNA-capture beads in a water-in-oil emulsion. 